\title{
Semantics of Lexicology in the Study of Arabic Phonemes and Lexemes
}

\author{
Nailul Izzah, M. Agus Mushodiq, Muhammad Syaifullah \\ Institut Agama Islam Ma'arif NU Metro Lampung \\ say_gheza12@gmail.com
}

Received: 09-01-2021

Revised: 12-01-2021

Accepted: 31-01-2021

\begin{abstract}
Linguistics is the name of the field of science, and the adjective is linguistic. Meanwhile in Arabic, the linguistic equivalent is known as Ilmu lughah or al-lisaaniyyat. The study of language is generally directed at four discussions. First, regarding the sounds of language. If the research of language sounds is carried out without looking at the sound function it is known as phonetic, whereas if the study of language sounds by looking at the sound function in language it is known as phonology. Second, the study of the form of the word (sharf). In the sharf, it is studied about changing the words of a language, where this science is known as morphology. Third, discussion of sentence structure (nahwu). The scope of study in Nahwu is the wording of a sentence in a language, this knowledge is known as syntax or grammar. Fourth, discussion about the good meaning of a word, sentence, or the meaning of an expression. This science is called semantics. Linguistics can be divided into two major branches, namely micro linguistics and macro linguistics. The object of micro linguistic study is the internal structure of the language itself, including the structure of phonology, morphology, syntax, and lexicon. While the object of factors outside of language is such as sociological, psychological, anthropological, and ethnolinguistic factors. The author will only discuss phonology (phoneme) and lexicology (lexeme) in an Arabic linguistic study using library research methods.
\end{abstract}

Keywords: Lexicology; Linguistics; Semantics

\begin{abstract}
Abstrak
Linguistik adalah nama bidang ilmu, dan kata sifatnya adalah linguitis. Sementara dalam bahasa Arab, padanan linguistik dikenal dengan sebutan ilmu lughah atau al-lisaaniyyat. Kajian tentang bahasa umumnya diarahkan pada empat pembahasan. Pertama, mengenai bunyi bahasa. Apabila penelitian bunyi bahasa dilakukan dengan tidak melihat fungsi bunyi tersebut dikenal dengan istilah phonetic, sedangkan apabila kajian bunyi bahasa dengan melihat fungsi bunyi tersebut dalam berbahasa maka dikenal dengan istilah phonology. Kedua, kajian mengenai bentuk kata (sharf). Dalam sharf dikaji mengenai perubahan kata suatu bahasa, di mana ilmu ini dikenal dengan morfhology. Ketiga, pembahasan mengenai tata kalimat (nahwu). Ruan lingkup kajian dalam nahwu adalah susunan kata sebuah kalimat dalam suatu bahasa, ilmu ini dikenal dengan syntax atau grammar. Keempat, pembahasan tentang makna baik makna sebuah kata, kalimat, atau makna sebuah ungkapan. Ilmu ini disebut dengan semantics. Linguistik dapat dibagi atas dua cabang besar, yaitu linguistik mikro dan linguistik makro. Objek kajian linguistik mikro adalah struktur internal bahasa itu sendiri, mencakup struktur fonologi, morfologi, sintaksis, dan leksikon. Sementara objek faktor-faktor di luar bahasa adalah seperti faktor sosiologis, psikologis, antropologis, dan etnolinguistik. Penulis hanya akan membahas tentang fonologi (fonem), dan leksikologi (leksem) didalam suatu kajian linguistik Arab dengan menggunakan metode penelitian kepustakaan.
\end{abstract}

Kata Kunci: Leksikologi; Linguistik; Semantik

(ㄷ) 2021 Nailul Izzah, M. Agus Mushodiq, Muhammad Syaifullah

(c) (i) (2)

This work is licensed under a Creative Commons Attribution-ShareAlike 4.0 International License.

\section{Pendahuluan}

Bahasa ialah sebuah sistem lambang bunyi yang arbitrer yang digunakan oleh masyarakat manusia untuk tujuan komunikasi. Sebagai sebuah sistem, bahasa itu bersifat sistematis dan sistemis. Bahasa dikatakan sistematis karena memiliki kaidah atau atauran tertentu. Bahasa juga 
bersifat sistemis karena memiliki subsistem, yakni subsistem fonologis, subsistem gramatikal, dan subsistem leksikal. Dalam ketiga subsistem itu bertemu dunia bunyi dan dunia makna. Bagannya sebagai berikut.

Bagan Sistem Bahasa:

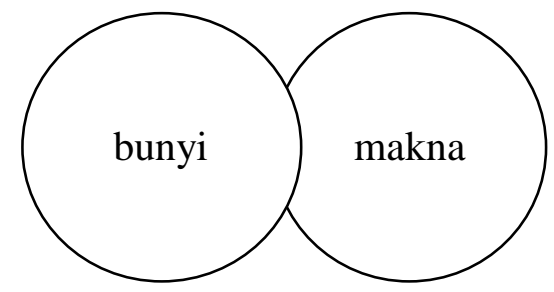

Subsistem fonologis membahas bunyi bahasa, subsistem gramatikal membicarakan struktur kata dan struktur kalimat, sedangkan subsistem leksikal membicarakan kosa kata suatu bahasa. Ketiga subsistem bahsa itu berkaitan dengan makna yang dikaji oleh semantik. Sistem bahasa dihubungkan dengan alam di luar bahasa oleh apa yang disebut pragmatik. Dalam hal ini, pragmatik berfungsi untuk menentukan serasi tidaknya sistem bahasa dengan pemakaian bahasa dalam komunikasi. ${ }^{1}$

Mengingat bahwa objek linguistik, yaitu bahasa, merupakan fenomena yang tidak dapat dilepaskan dari segala kegiatan manusia bermasyarakat. Berdasarkan objek kajiannya, apakah struktur internal bahasa atau bahasa itu dalam hubungannya dengan faktor-faktor di luar bahasa dibedakan adanya linguistik mikro (mikrolinguistik) dan linguistik makro (makrolinguistik). ${ }^{2}$ Linguistik mikro mengarahkan kajiannya pada struktur internal suatu bahasa tertentu atau struktur internal suatu bahasa tertentu atau struktur internal bahasa pada umumnya. Sejalan dengan adanya subsistem bahasa, maka dalam linguistik mikro ada subdisiplin linguistik fonologi (الأصوات), morfologi (بناء الكلمة/مورفولوجى), sintaksis (بناء الجملة), semantik (الدلالة), dan leksikologi

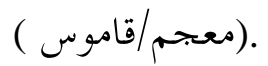

Didalam artikel ini, penulis hanya akan membahas tentang fonologi (fonem), dan leksikologi (leksem) didalam suatu kajian linguistik Arab. Dalam artikel ini dikategorikan sebagai penelitian kepustakaan. Jadi metode ini menggali datanya dari bahan-bahan tertulis (khususnya berupa teori-teori), ${ }^{3}$ yaitu meneliti buku-buku atau majalah, dan sebagainya yang ada sangkut pautnya dengan permasalahan yang diteliti. Dalam pengumpulan data, penulis menggunakan metode dokumentasi untuk mencari data yang bersangkutan dengan fokus atau masalah-masalah yang bersumber dari buku-buku, transkrip, catatan, majalah, surat kabar, dan lain-lain. ${ }^{4}$ Sedangkan metode analisis data menggunakan deskriptif analitik, yaitu suatu cara pengambilan kesimpulan yang berdasarkan atas fenomena-fenomena dan fakta-fakta untuk mengetahui unsur-unsur suatu kesatuan yang menyeluruh kemudian mendeskripsikannya dalam suatu kesimpulan dengan menggunakan cara berfikir.

1 Yayat Sudaryat, Makna Dalam Wacana "Prinsip-prinsip Semantik dan Pragmatik, (Bandung: Alfabeta, 2006), hlm. 8.

2 Abdul Chaer, Linguistik Umum, (Jakarta: Rineka Cipta, 1994), hlm.13-15.

3 Tatang M. Amirin, Menyusun Rencana Penelitian, (Jakarta: Rajawali Press, 1986), hlm. 133

4 Suharsimi Arikunto, Prosedur Penelitian, (Jakarta: Rineka Cipta, 1989), hlm. 139 


\section{Hasil dan Pembahasan}

A. Fonem

1. Pengertian dan Identifikasi Fonem

Fonem sebuah istilah linguistik dan merupakan satuan terkecil dalam sebuah bahasa yang masih bisa menunjukkan perbedaan makna. Fonem berbentuk bunyi. Misalkan dalam bahasa Indonesia bunyi [k] dan [g] merupakan dua fonem yang berbeda, misalkan dalam kata "cagar" dan "cakar". Tetapi dalam bahasa Arab hal ini tidaklah begitu. Dalam bahasa Arab hanya ada fonem $/ \mathrm{k} /$.

Sebaliknya dalam bahasa Indonesia bunyi [f], [v] dan [p] pada dasarnya bukanlah tiga fonem yang berbeda. Kata provinsi apabila dilafalkan sebagai [propinsi], [profinsi] atau [provinsi] tetap sama saja

Contoh: bunyi [k] dan [g] pada kata "pakar" dan "pagar". bunyi [p] dan [m] pada kata "palu" dan "malu".

Dalam kamus besar bahasa indonesia mendefinisikan, ${ }^{5}$ fonem dalam kajian linguistik adalah satuan bunyi terkecil yang mampu menunjukkan kontras makna, misal $/ \mathrm{h} /$ adalah fonem karena membedakan makna kata harus dan arus. /b/ dan /p/ dua fonem yang berbeda karena bara dan para berbeda maknanya.

Ferdinand de Saussure, ahli bahasa Swis mengatakan, bahwa bunyi bahasa itu bersifat dua, yaitu bersifat ujar (parole) dan bersifat sistem (langue). Untuk membedakan kedua macam bunyi itu, dipakailah istilah yang berbeda pula, yang pertama disebut bunyi (fon), yang kedua disebut fonem. Ilmu yang mempelajari yang pertama disebut fonetik (ilmu bunyi), dan yang kedua disebut fonemik (ilmu fonem). ${ }^{6}$

Fonem merupakan objek kajian penelitian fonemik (fon), yaitu bunyi bahasa pada umumnya tanpa memperhatikan apakah bunyi tersebut mempunyai fungsi sebagai pembeda makna kata atau tidak. Kalau dalam fonetik, misalnya, kita meneliti perbedaan bunyi [i] seperti yang terdapat pada kata-kata ini, intan, dan pahit; maka dalam fonetik kita meneliti apakah perbedaan bunyi itu mempunyai fungsi sebagai pembeda makna atau tidak. Jika bunyi itu membedakan makna, maka bunyi tersebut kita sebut fonem, dan jika tidak membedakan makna adalah bukan fonem.

Untuk mengetahui apakah sebuah bunyi fonem atau bukan, kita harus mencari sebuah satuan bahasa, biasanya sebuah kata, yang mengandung bunyi tersebut, lalu membandingkannya dengan satuan bahasa lain yang mirip dengan satuan bahasa yang pertama. Misalnya, kata Indonesia laba dan raba. Kedua kata itu mirip benar, yang masing-masing terdiri dari empat buah bunyi. Jika dibandingkan

[1], [a], [b], [a]

$[\mathrm{r}],[\mathrm{a}],[\mathrm{b}],[\mathrm{a}]$

5 http://ebsoft.web.id/KBBI v1.1. Kamus Besar Bahasa Indonesia.

${ }^{6}$ Samsuri, Analisis Bahasa "Memahami Bahasa Secara Ilmiah, (Jakarta: Erlangga, 1987), hlm. 125. 
Ternyata perbedaannya hanya pada bunyi yang pertama, yaitu bunyi [1] dan bunyi [r]. Maka dengan demikian dapat disimpulkan bahwa kedua bunyi itu adalah dua buah fonem yang berbeda di dalam bahasa indonesia. ${ }^{7}$

Contoh fon (bunyi) dalam bahasa Arab:

- Kata: بيْت ( Rumah ) = Kata yang mengandung empat Fon / Bunyi yakni :

$$
-\mathrm{Ba} \quad-\text { Fathah } \quad-\text { Ya } \quad-\mathrm{Ta}
$$

Contoh fonem dalam bahasa Arab:

- Kata: بيْت مuيْت Kata yang ) dan mengandung empat fon/Bunyi :

$$
\begin{aligned}
& \text { بيْت - Ba - Fathah -Ya -Ta } \\
& \text { = - Ma - Fathah -Ya -Ta }
\end{aligned}
$$

Terdapat perbedaan hanya pada bunyi pertama, yaitu [Ba] dan bunyi [Ma]. Maka kedua bunyi itu adalah dua fonem yang berbeda.

- Bunyi pada ينتل dan kata

2. Kesulitan Pengucapan dan Kesalahan

Ketika siswa non-Arab yang belajar bahasa Arab terdapat kesulitan yang dihadapi yang berhubungan dengan pengucapan. Kesulitan ini disebabkan oleh beberapa faktor:

a. Siswa terkadang terasa sulit mengucapkan beberapa bunyi bahasa Arab yang tidak ada dalam bahasa ibu.

b. Siswa mendengar beberapa bunyi bahasa Arab yang samar yang menyerupai suara-suara dalam bahasa ibunya, dan bersama gurunya siswa mencari letak perbedaan bunyi tersebut.

c. Siswa suka keliru dalam mengenali apa yang didengar, maka dalam ucapannya itupun berdasar yang dia dengar, maka kesalahan dengar ini jadi kesalahan ucap.

d. Siswa suka keliru dalam mengenali perbedaan yang penting antara beberapa bunyi bahasa Arab dan mengira hal itu tak penting karena diukur dengan bahasa ibunya, maka bunyi tak berbeda

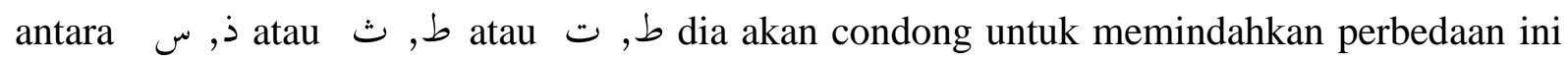
sebagaimana yang ia dengar dalam bahasa Arab/ketika mengucapkan dalam bahasa Arab.

e. Siswa kadang lemah dalam bahasa Arab yang fasih, yang ditunjang bahasa ibunya. Maka orangorang Amerika cenderung mengidlofatkan bunyi P/V untuk bahasa Arab, karena bunyi tersebut digunakan dalam bahasa ibunya.

f. Siswa kadang mengucapkan bunyi bahasa Arab sebagaimana yang diucapkan dalam bahasa ibunya, tidak seperti mengucapkan dalam bahasa Arab yang benar, seperti orang Amerika JIka mengucapkan $ت$ bahasa Arab, karena itu titik artikulasinya (gusi) harus diubah pada gigi, dan hal ini bias berhasil dengan menganalogikan bahasa Arab.

7 Abdul Chaer, Linguistik Umum...., hlm.125. 
g. Siswa merasa sulit mengucapkan bunyi-bunyi bahasa Arab adapun untuk mengungkapkan ذ, و, ت ت lafal-lafal dengan perilaku tertentu. Untuk itu sulit untuk meniru ucapan

h. Kadang terdapat bunyi yang bersekutu antara bahasa Arab dengan bahasa ibu, tapi bunyi ini membuat kesulitan siswa dalam berbagai posisi. Maka untuk orang Inggris tidak mengucapkan - dalam kata yang lain dalam bahasa ibunya, memaksa bahwa hal itu mengucapkannya di awal kata/tengah. Untuk itu jika • di akhir kata dalam bahasa Arab akan sulit dalam ucapan siswasiswa Inggris/Amerika.

i. Diantara bunyi-bunyi yang sulit yang dirasakan oleh non-Arab adalah ط, ظ, ص, ض semua ini adalah bunyi-bunyi yang berat atau dilembutkan/dilipatkan yang diucapkan dengan ditafhimkan, yaitu melipat atau memutar dan siswa juga sulit dalam membedakan dari

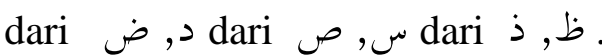

j. Bunyi yang sulit $\dot{\tau}$ dan $\dot{\varepsilon}$ bahkan untuk membedakan keduanya kadang sulit pula bagi siswa Arab.

k. Seperti itu sulit untuk non-Arab dalam mambedakan o dan $ح$, ق, ك,

1. Non-Arab sulit membedakan antara sdan fathah pendek.

m. Siswa sulit mengenali perbedaan antara fathah pendek dan panjang seperti سمر dan

n. Sulit membedakan antara dlommah pendek dan panjang dan قوتل, قتل

o. Sulit membedakan antara kasroh pendek dan panjang dan زير, زر

p. Sulit untuk mengucapkan, Arab yang bergetar diulang-ulang. Kadang-kadang mengucapkannya seperti orang Amerika atau tidak diucapkan apabila ditemukan sebagaimana orang Inggris mangucapkannya. ${ }^{8}$

Sebagian dari kesalahan-kesalahan stress yang dihadapi siswa Arab dengan siswa nonArab, sebagai berikut:

1) Kadang-kadang siswa memberi tekanan pokok dalam satu maqothi bukan maqothi yang benar.

2) Kebanyakan kemunculan tekanan bukan pada tempatnya, yaitu memanjangkan vokal yang pendek, seperti صام, kemunculan itu merubah artinya.

3) Kadang-kadang siswa memberi tekanan pokok satu saja untuk satu kata, perbedaan itu untuk pedoman untuk tekanan bahasa Arab yang memberikan satu tekanan pokok untuk satu kata.

4) Kadang-kadang siswa memindahkan aturan tekanan dari bahasa ibunya ke dalam bahasa Arab yang dipelajarinya, membicarakan kerusakan atau ketidaksesuaian dalam tekanan bahasa Arab.

5) Jika kata mempunyai lima maqothi, maka tekanan pokok diletakan pada maqothi ke tiga, kecuali jika maqothi ke empat atau ke lima panjang, seperti transfer pengaruh pendidikan.

Disaat siswa menunjukkan kemampuannya dalam bahasa Arabnya, sebelumnya telah tumbuh kebiasan-kebaisaan bahasa tertentu yang didapatkannya dari lingkungan bahasa ibunya yang ia pelajari. Pada posisi ini, kebiasaan-kebiasaan mempelajari bahasa pertama yang digunakan dalam dua segi yang berbeda:

$$
\text { ^ محمد علي الخولي, أساليب تلدبيس اللغة العربية, الطبعة الثالثة, (الرياض: العرردق التجارنية, } 1919 \text { ), ص. جـ }
$$


a) Sebagian dari kebiasaan bahasa yang pertama, dapat membantu siswa dalam pengajaran bahasa Arabnya, dan hal itu terdapat kesamaan antara bahasa Ibu dengan bahasa Arab. Maka jika dalam konten bahasa Ibu terdapat bunyi bahasa yang juga terdapat dalam bahasa Arab baik makhrojnya maupun komponennya, maka faktor ini dapat membantu dalam mempelajari bahasa Arab. Transfer pengaruh pendidikan di sini merupakan faktor yang mempermudah dalam pendidikan ketrampilan yang baru.

b) Sebagian dari kebiasaan bahasa pertama, dapat menghambat pengajaran bahasa Arab. Hal itu dikarenakan terdapat sesuatu yang dapat merusak atau menghalangi antara sound system yang ada dalam bahasa Ibu dengan yang ada dalam bahasa Arab. Bunyi-bunyi itu terkadang keluar dari bahasa pertama yang berpengaruh terhadap bahasa Arab ketika diucapkan oleh siswa, dan siswa akan mengalami kesulitan ketika mengucapkan bunyi-bunyi bahasa Arab, karena tidak terdapat dalam bahasanya. Transfer pengaruh pendidikan di sini adalah faktor yang mengahmbat pendidikan bahasa modern. ${ }^{9}$

Dalam pemilihan sifat suatu bunyi, akan mendatangkan suatu kesulitan pengucapan dalam suatu pembelajaran bahasa, sehingga harus memiliki waktu dan kesungguhan dalam memilih permasalahan tentang bunyi.

Adanya banyak perbedaan antar negara dalam pembelajaran bunyi di sekolahan dengan bunyi-bunyi dalam bahasa Arab, terdapat di dalam bahasa mereka suatu bunyi yang menyerupai dalam bahasa Arab akan tetapi tidak merubah makna, terdapat di dalam bahasa mereka suatu bunyi yang menyerupai akan tetapi perubahan suatu makna, tidak terdapat di dalam bahasa mereka sebagian bunyi-bunyi yang terdapat di bahasa Arab. Seperti yang terdapat pada fon / / tidak sama kesulitan bagi pembelajar Bangladesh (India) dan Inggris. Ketika menemukan fon / j / yang terdapat dalam pembelajaran bahasa Bangladesh (India), akan tetapi berlawan dengan pembelajaran bahasa Arab. Bagi mereka merupakan suatu kesulitan yang sangat berat dalam pengucapannya ketika terdapat di awal suatu kalimat, seperti kalimat; “ زميل bagi meraka menjadi " جميل ". 10

\section{Perbedaan-perbedaan Fon (bunyi) (الصوتية dan Fonem ( الفنو نيمية )}

Tak dapat disangkal lagi bahwa siswa tingkat dasar akan mendapatkan kesulitan dalam mengucapkan bahasa Arab sebagaimana yang diucapkan oleh ahlinya. Maka yang patut diperhatikan adalah pemindahan hal yang baru dan yang utama yang akan nampak dalam pengucapannya, hal itu menunjukkan bahwa pengucapan bahasa Arab merupakan bahasa kedua. Tentu akan berbeda pengucapan kosa-katanya dibanding dengan pengucapan orang-orang Arab. Kalau demikian, apakah dibenarkan guru yang memberikan kemudahan dalam hal atau siswa yang harus dituntut mengucapkan bahasa Arab dengan sempurna sebagaimana yang diucapkan oleh ahlinya?

Untuk menjawab pertanyaan itu ada dua hal yang mesti dibedakan:

a. Perbedaan-perbedaan bunyi, yang dimaksud dengan perbedaan bunyi disini adalah yang pengucapannya tidak merubah arti. Apabila siswa mengucapkan / ت / yang menjadikan gusi sebagai titik artikulasi, dan sebagai pergantian dari gigi, perbedaan ini dari segi bunyi saja, karena ini tidak mempengaruhi dari segi makna. Dan apabila siswa mengucapkan / د / yang menjadikan gusi sebagai titik artikulasi, dan sebagai pergant ian dari gigi, perbedaan ini dari segi bunyi juga, karena tidak mempengaruhi dari segi makna. Juga jika siswa mengucapkan /

$$
\begin{aligned}
& 9 \text { " محمد علي الخولي, أساليب تدريب اللغة العربية, ص. ص. } 9 \text { ؛ . }
\end{aligned}
$$

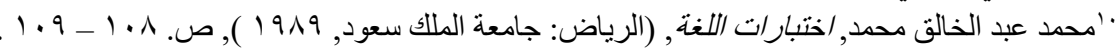


J/ dalam bahas Arab yang menjadikan anak tekak menjadi bergetar, perbedaan ini dari segi bunyi, dan tidak mempengaruhi makna. Karena itu guru boleh saja bersikap masa bodoh dari masalah ini. Kita tidak mengatakan dia berani bertindak demikian, akan tetapi kita mengatakan bahwa dia terkadang bisa saja berpura-pura tidak tahu karena perhatian perhatian ini untuk kesalahan yang lebih besar yaitu merusak.

b. Perbedaan fonem, yang dimaksud dengan perbedaan fonem adalah perbedaan yang mempengaruhi makna. Jika siswa mengucapkan / زال / سال / pengganti dari maka ini adalah perbedaan dan kekeliruan fonem, karena mempengaruhi makna. Perbedaan antara / dalam bahasa Arab adalah juga perbedaan fonem. Begitu juga perbedaan antara pasangan

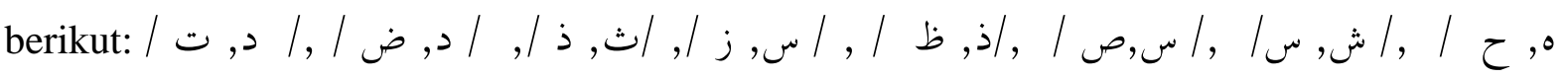

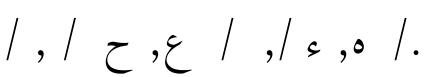

Contoh perbedaan fonem ini adalah perbedaan penting yang tidak bisa dianggap enteng, sebagaimana harus memperhatikan pasangan dalam bahasa Arab, dalam kosa-katanya dan bunyibunyi bahasanya. Sedangkan perbedaan bunyi itu dapat saja menjadi urutan yang mesti diperhatikan sesudah perbedaan fonem. Bersama dengan itu, guru membuat contoh dalam pengucapan pada sekelompok bentuk atau keadaan.

Salah-satu metoda yang terbaik untuk menunjukkan perbedaan-perbedaan yang jelas dengan melanggengkan pasangan-pasangan kecil. Yang dimaksud dengan pasangan ini adalah dua kata yang berbeda dalam makna, sama dalam ucapannya, kecuali dalam posisi satu bunyi, seperti زال , Dan posisi itu ada yang di awal, di tengah, atau di akhir.

Dari contoh-contoh kontras perbedaan itu adalah:

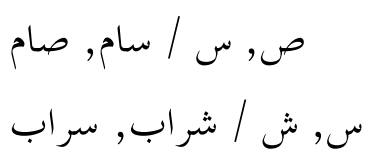

Contoh kontras di tengah:

$$
\text { ز, ث, ك / لكم, الثم }
$$

Contoh kontras di akhir:

$$
\begin{aligned}
& \text { ف, ت / اصوات, اصواف } \\
& 11
\end{aligned}
$$

Pasangan-pasangan ini bermanfaat bagi guru dalam beberapa hal :

1) siswa dilatih untuk memebedakan bunyi-bunyi yang hampir sama dengan yang berbeda tajam.

2) tampak perbedaan pasangan kecil yang pendek/ sedikit dalam satu posisi, yang dapat dengan segera siswa memusatkan perhatian untuk membedakan antara dua bunyi saja dalam setiap pasangan yang disimak atau diucapkan.

3) siswa memberi tanda lain atau contoh lain untuk setiap pengaruh perbedaan antara bunyi dalam satu makna. 


\section{B. Leksem}

\section{Pengertian dan Identifikasi Leksem}

Definisi Leksem adalah istilah yang lazim digunakan dalam studi semantik untuk menyebut satuan bahasa bermakna. Istilah leksem kurang lebih dapat dipadankan dengan istilah kata yang lazim digunakan dalam studi morfologi dan sintaksis dan yang lazim didefinisikan sebagai satuan gramatikan bebas terkecil. Hanya bedanya sebagai satuan semantik, leksem dapat berupa sebuah kata seperti kata meja, kucing dan makan dapat juga berupa gabungan kata seperti meja hijau dalam arti "pengadilan", bertekuk lutut dalam arti 'menyerah' dan tamu yang tidak diundang dalam arti 'pencuri'. Kumpulan dari leksem suatu bahasa disebut leksikon. Dalam studi morfologi leksem ini sering diartikan sebagai satuan abstrak yang setelah melalui proses morfologi akan membentuk kata. Misalnya leksem "WRITE" dalam bahasa Inggris yang setelah melalui proses morfologi menjadi kata write, writes, writing, wrote dan writer. Dalam bahasa Indonesia, leksem "PUKUL" yang setelah mengalami proses afiksasi akan menjadi kata seperti memukul, pikiran, pemukul dan pemukulan. Contoh kata كاتب merupakan Morf, dengan Morfem فاعـــ Yang bermakna Al-Musyarakah. Begitupula dengan kata استفعل yang bermorfem استغفـــــ

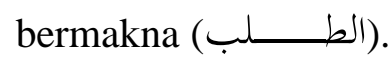

Leksem dalam kamus bahasa Indonesia adalah satuan leksikal dasar yang abstrak yang mendasari pelbagai bentuk kata, atau juga satuan terkecil dari leksikon. Leksikal ialah yang berkaitan dengan kata, leksem, dan juga kosa kata. Sedangkan leksikon ialah kosa kata, kamus sederhana, daftar istilah dari suatu bidang disusun menurut abjad dan dilengkapi dengan keterangannya, atau kekayaan kata yang dimiliki suatu bahasa. ${ }^{12}$

Sebenarnya, istilah leksem sudah dipergunakan oleh Whorf pada tahun 1938. Dalam salah satu karangannya, pelopor relativitas bahasa itu menerangkan bahwa "The lexeme....." adalah "......the word or stem as an item of the vocabulary, and as a part analyzed or abstracted from sentence words". Dalam karangan ini ia mempergunakan leksem sebagai satuan dasar dalam leksikon dan dibedakan dari kata sebagai satuan gramatikal (sesuai dengan tata bahasa). Dengan kata lain, leksemlah yang merupakan "bahan dasar" yang setelah mengalami "pengolahan gramatikal" menjadi kata dalam subsistem gramatika. ${ }^{13}$

Jadi, dengan ringkas dapat dinyatakan bahwa leksem adalah:

a) Satuan terkecil dalam leksikon,

b) Satuan yang berperan sebagai input dalam proses morfologi,

c) Bahan baku dalam proses morfologis,

d) Unsur yang diketahui adanya dari bentuk yang setelah disegmentasikan dari bentuk kompleks merupakan bentuk dasar yang lepas dari proses morfologi,

e) Bentuk yang tidak tergolong proleksem atau partikel.

Istilah leksem dalam leksikon dapat disamakan dengan istilah morfem dalam morfologi. Karena itu, jika morfem sebagai pemadu kata, leksem sebagai pemadu kosa kata atau leksikon. Singkatnya, leksem adalah satuan leksikal terkecil yang sama atau mirip yang berulang sebagai pemadu leksikon. Penggunaan konsep leksem dan pembedaannya dengan konsep kata dapat menghilangkan keragu-raguan orang selama ini dalam menentukan kriteria kata.

2. Perwujudan Leksem: Lekson dan Aloleks

12 http://ebsoft.web.id/KBBI v1.1. Kamus Besar Bahasa Indonesia.

${ }^{13}$ Harimurti Kridalaksana, Pembentukan Kata dalam Bahasa Indonesia, Edisi Kedua, (Jakarta: PT Gramedia Pustaka Utama, 1996), hlm. 9-10. 
Lekson (tata bahasa stratifikasi) ialah komponen dari leksem. Misalnya: unsur-unsur =tidak' dan _ajakan' adalah lekson-lekson yang membentuk leksem jangan. Istilah lain untuk lekson ialah leksis. Jika kita bandingkan istilah leksokon, leksem, lekson, dan alolek dalam tataran leksikologi, maka sejalan dengan istilah kata, morfem, morf, dan alomorf dalam tataran morfologi. Perhatikan bagan di bawah ini. Perbandingan Morfologi dan Leksikologi seperti bagan dibawah ini: ${ }^{14}$

\begin{tabular}{|c|c|c|}
\hline Tataran & Morfologi & Leksikologi \\
\hline Satuan terbesar & kata & leksikon \\
\hline Satuan terkecil & morfem & leksem \\
\hline Ujaran aktual & morf & lekson \\
\hline Varian & alomorf & aloleks \\
\hline
\end{tabular}

Pembahasan leksikon dan aloleks berkaitan erat dengan leksem. Leksem diwakili oleh lekson, bisa satu lekson atau beberapa lekson. Lekson-lekson itu tersusun dari fonem-fonem, dan masing-masing lekson dibedakan oleh bentuk fonemis dan

maknanya. Karena itu, lekson dapat berupa:

a. fonem atau urutan fonem yang berasosiasi dengan suatu makna;

b. anggota leksem yang belum ditentukan distribusinya; dan

c. ujud konkret atau fonemis dari leksem;

Beberapa lekson yang berbeda-beda bentuknya terwakili oleh satu semem, dan disebut aloleks. Jadi, aloleks adalah anggota satu leksem yang ujudnya berbeda, tetapi mewakili fungsi dan makna yang sama, atau anggota leksem yang telah ditentukan distribusinya.

Untuk lebih menjelaskan leksem, lekson, dan aloleks, perhatikan contoh berikut. Leksem India memiliki struktur (India, Indo-), leksem sosial memiliki struktur (Sosial, sosio-), dan sebagainya. India, Indo-; sosial, sosio- masing-masing merupakan lekson, yang semuanya aloleks (anggota leksem yang sama) dari India dan sosial.

3. Pembentukan Leksikal

Dalam proses leksemik dan proses morfologis, leksem sebagai satuan berperanan sebagai masukan; sedangkan kata sebagai satuan gramatikal ber- peranan sebagai hasilan. Proses ini dapat digambarkan sebagai berikut.

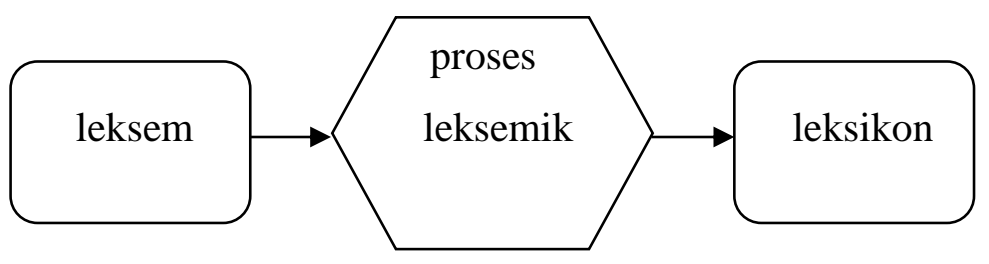

bandingkan dengan proses morfologis berikut.

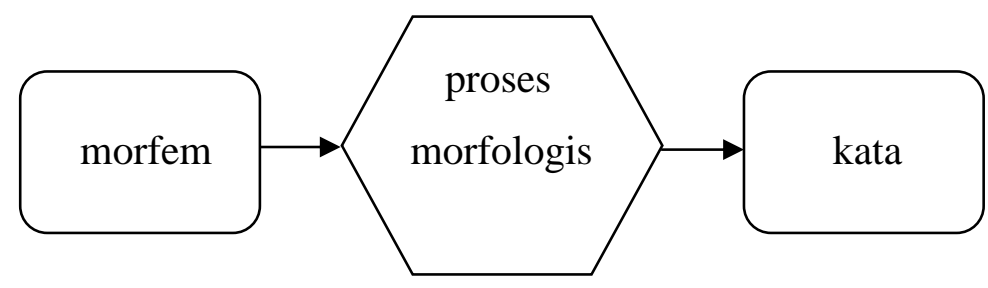

14 Yayat Sudaryat, Makna Dalam Wacana "Prinsip-prinsip Semantik dan Pragmatik, hlm. 77. 
Terdapat aneka proses leksemik atau leksikalisasi yang sejalan dengan proses morfologis, antara lain, derivasi zero, afiksasi (pengimbuhan), reduplikasi, abreviasi (pemendekan), derivasi balik, dan komposisi (perpaduan).

a. Derivasi Zero (Perubahan Tanwujud)

Derivasi zero atau perubahan tanwujud ialah proses leksemik yang mengolah leksem tunggal menjadi (kosa) kata tunggal. Dalam proses ini leksem menjadi kata tunggal tanpa perubahan apa-apa. Misalnya: leksem lupa menjadi kata lupa. Agar lebih jelas, perhatikan bagan berikut.

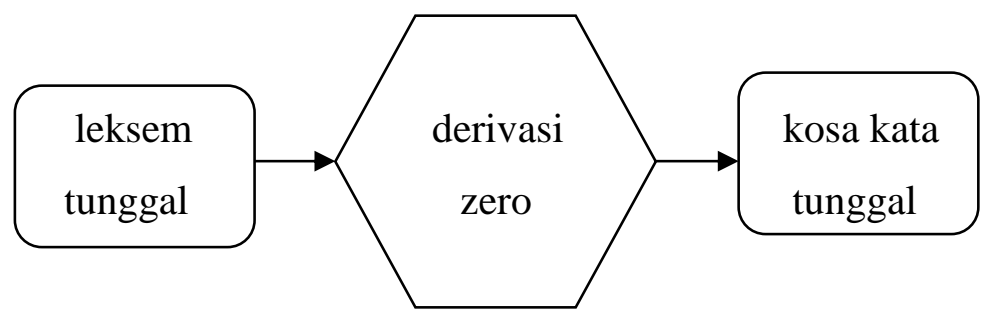

b. Afikasasi (Pengimbuhan)

Afiksasi ialah proses leksemik yang mengubah leksem tungal menjadi kosa kata berimbuhan. Misalnya: leksem lupa menjadi kata melupakan setelah mengalami afiksasi dengan meN- - kan.

c. Reduplikasi (Pengulangan)

Reduplikasi ialah proses leksemik yang mengubah leksem menjadi kata kompleks dengan jalan penyebutan leksem sebagian atau seluruhnya. Misalnya: leksem rumah menjadi kata rumahrumah.

d. Pemendekaan (Abreviasi)

Pemendekan ialah proses leksemik yang mengubah leksem atau gabungan leksem menjadi kata kompleks atau akronim (singkatan). Ada beberapa jenis pemendekan:

1) pemenggalan (reduksi), misalnya: ibu menjadi bu;

2) haplologi, misalnya: leksem tak dan akan menjadi takkan;

3) akronim, misalnya: leksem bukti dan pelanggaran menjadi kata tilang; dan

4) penyingkatan, misalnya leksem-leksem sekolah, menengah, dan atas menjadi SMA.

Dalam proses leksemik akronimi dan penyingkatan (abreviasi), leksem sebagai masukan lebih dari sebuah. Oleh karena itu, bagannya sebagai berikut:

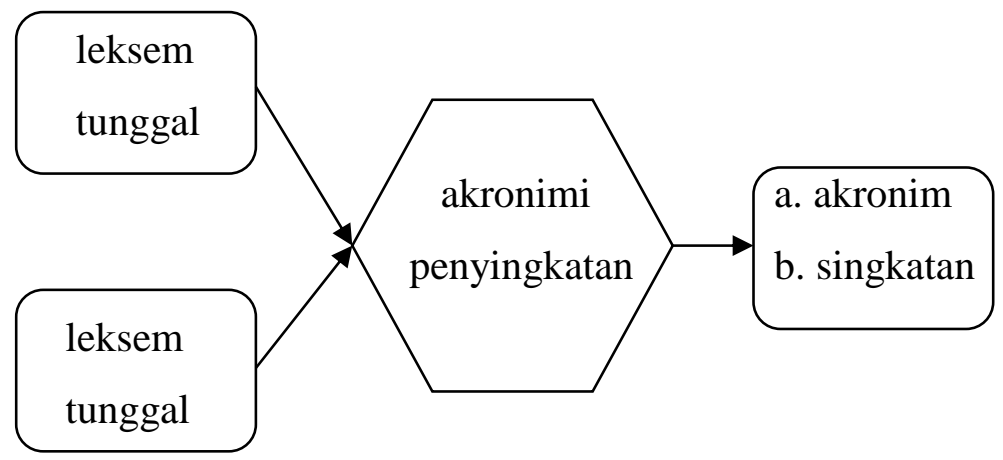

Proses leksemik itu berbeda dengan proses leksemik pada afiksasi, reduplikasi, pemenggalan, dan kontraksi yang mempunyai masukan leksem tunggal. Bagannya adalah sebagai berikut.

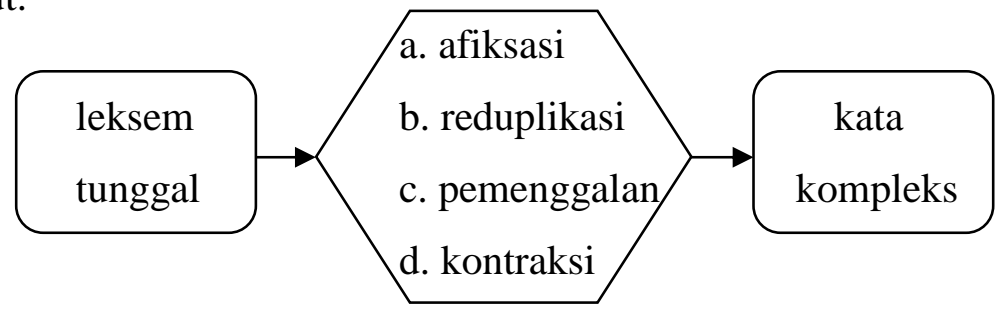




\section{e. Derivasi Balik}

Derivasi balik ialah proses leksemik yang masukkannya berupa leksem tunggal, dan hasilannya berupa kata yang secara historis muncul kemudian dari asalnya itu, kejadiannya seperti afiksasi. Misalnya: Leksem mungkir menjadi pungkir dalam bentuk seperti dipungkiri terjadi karena proses derivasi balik. Kita tahu bahwa leksem mungkir lebih dulu ada daripada leksem pungkir, karena leksem itu berasal dari bahasa Arab dan pungkir hanya ada dalam bahasa Indonesia.

f. Perpaduan (Pemajemukan)

Perpaduan adalah proses leksemik yang menggabungkan beberapa leksem tunggal menjadi kata kompleks. Misalnya leksem daya dengan leksem juang menjadi kata daya juang. Proses ini dapat dibagankan sebagai berikut:

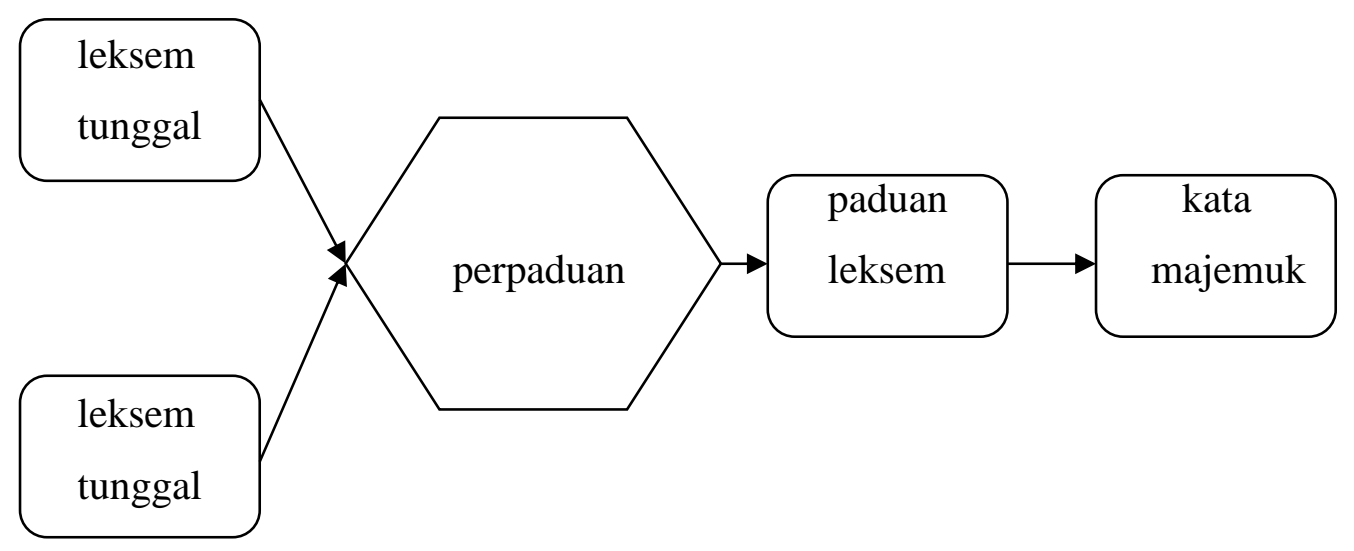

Kata majemuk yang dihasilkan oleh proses perpaduan yang bersifat morfologis atau leksemik berbeda dari frasa yang merupakan penggabungan kata secara sintaksis. terjadinya kontruksi frasa akan terlihat dalam bagan berikut:

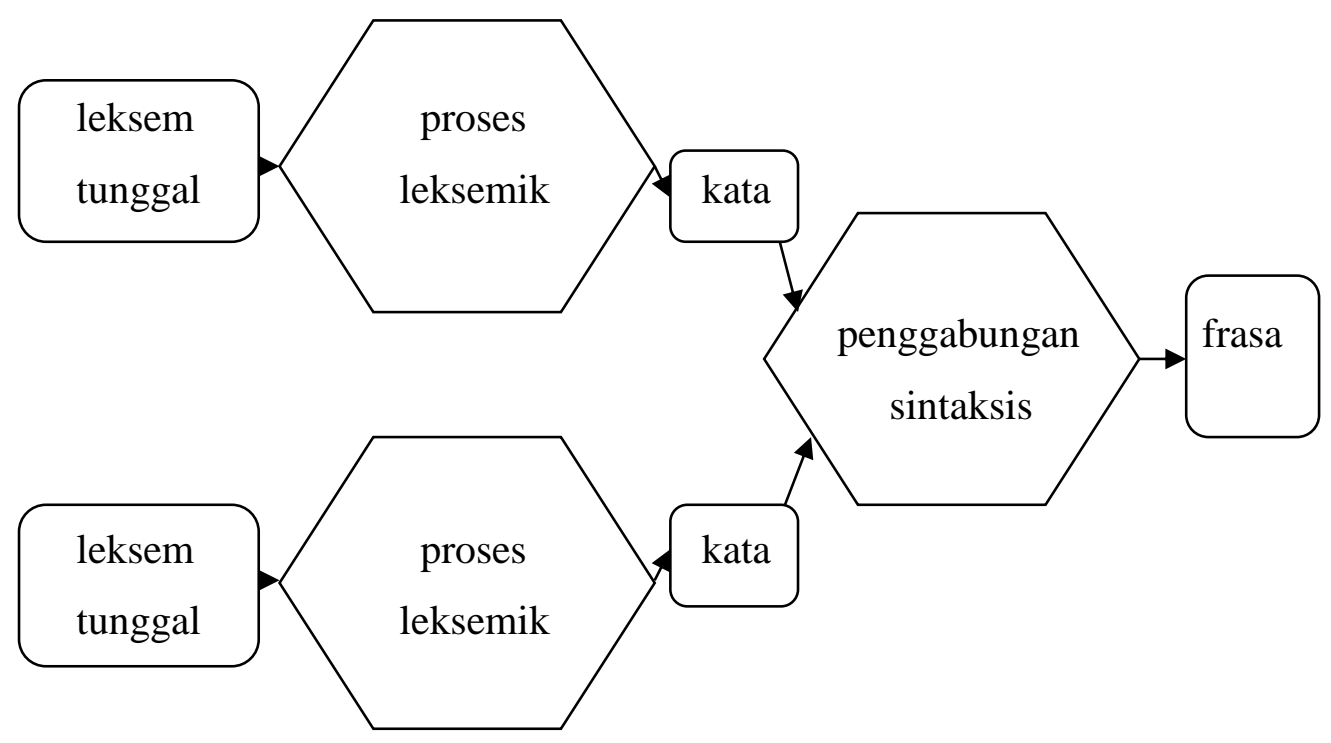

Misalnya, leksem teman menjadi kata teman dengan derivasi zero, dan leksem main menjadi bermain dengan afiksasi ber-. Kedua kata itu bergabung secara sintaksis menjadi frasa teman bermain.

Pembentukan kosa kata dalam bahasa Indonesia bersifat rekursif; sebuah leksem atau lebih setelah mengalami proses morfologis menjadi kata, dan unsur ini kemudian dapat mengalami 
proses morfologis lagi menjadi kata "baru". Berubahnya leksem menjadi kata disebut proses gramatikalisasi, dan kembalinya kata menjadi unsur leksikal lagi disebut proses leksikalisasi. ${ }^{15}$

Tabel pada unsur-unsur dalam morfologis

\begin{tabular}{|c|c|c|c|c|c|}
\hline Bentuk & Keterikatan & Perluasan & Kelas & Makna & Contoh \\
\hline afiks & pada dasar & tidak bisa & Tidak bisa & gramatikal & ber-, -an \\
\hline proleksem & pada dasar & tidak bisa & ada & leksikal & $\begin{array}{l}\text { se-, aneka-, } \\
\text { panca-, multi- }\end{array}$ \\
\hline $\begin{array}{l}\text { morfem dasar } \\
\text { terikat }\end{array}$ & $\begin{array}{l}\text { 1. pada afiks, } \\
\text { atau } \\
\text { 2. pada morfem } \\
\text { dasar lain }\end{array}$ & bisa & belum ada & leksikal & $\begin{array}{l}\text { juang, temu, } \\
\text { olah }\end{array}$ \\
\hline klitik & $\begin{array}{l}\text { 1. Pada kata } \\
\text { 2. Berpadanan } \\
\text { dengan kata } \\
\text { serupa }\end{array}$ & tidak bisa & ada & leksikal & kau, mu, nya \\
\hline partikel & $\begin{array}{l}\text { ada yang terikat, } \\
\text { ada yang bebas }\end{array}$ & tidak bisa & ada & $\begin{array}{l}\text { ada yang } \\
\text { gramatikal } \\
\text {, ada yang } \\
\text { leksikal }\end{array}$ & $\begin{array}{l}\text { pada, karena, } \\
\text { dong, wah, } \\
\text { agak }\end{array}$ \\
\hline kata & bebas & bisa & ada & leksikal & $\begin{array}{l}\text { rumah, istri, } \\
\text { pulau }\end{array}$ \\
\hline
\end{tabular}

\section{Penutup}

Fonem merupakan objek kajian penelitian fonemik (fon), yaitu bunyi bahasa pada umumnya tanpa memperhatikan apakah bunyi tersebut mempunyai fungsi sebagai pembeda makna kata atau tidak. Kalau dalam fonetik, misalnya, kita meneliti perbedaan bunyi [i] seperti yang terdapat pada kata-kata ini, intan, dan pahit; maka dalam fonetik kita meneliti apakah perbedaan bunyi itu mempunyai fungsi sebagai pembeda makna atau tidak. Jika bunyi itu membedakan makna, maka bunyi tersebut kita sebut fonem, dan jika tidak membedakan makna adalah bukan fonem. Jadi fonem itu adalah sebuah istilah linguistik dan merupakan satuan terkecil dalam sebuah bahasa yang masih bisa menunjukkan perbedaan makna.

Leksem dalam studi morfologi sering diartikan sebagai satuan abstrak yang setelah melalui proses morfologi akan membentuk kata. leksem dapat berupa sebuah kata seperti kata meja, kucing dan makan dapat juga berupa gabungan kata seperti meja hijau dalam arti "pengadilan", bertekuk lutut dalam arti 'menyerah' dan tamu yang tidak diundang dalam arti 'pencuri', kumpulan dari leksem suatu bahasa disebut leksikon. Terdapat aneka proses leksemik atau leksikalisasi yang sejalan dengan proses morfologis, antara lain, derivasi zero, afiksasi (pengimbuhan), reduplikasi, abreviasi (pemendekan), derivasi balik, dan komposisi (perpaduan). Sedangkan Makna leksikal adalah makna yang dimiliki atau ada pada leksem meski tanpa konteks apa pun. Misalnya, leksem "kuda" memiliki makna leksikal 'sejenis binatang berkaki empat yang bisa dikendarai'. Dengan contoh itu dapat juga dikatakan bahwa makna leksikal adalah makna yang sebenarnya, makna yang sesuai dengan hasil observasi indra kita, atau makna apa adanya.

\footnotetext{
${ }^{15}$ Harimurti Kridalaksana, Pembentukan Kata dalam Bahasa Indonesia, Edisi Kedua, hlm. 12-14.
} 


\section{Bibliografi}

Al-Kholiq, Muhammad 'Abdu Muhammad. Ikhtibarot al-Lughah. al-Riyad: Jami'ah al-Malik Su'udi. 1989.

Al-Khuwali, Muhammad 'Ali. Asalib Tadris al-Lughah al-Arobiyah. At-Thobaq As-Sthalisah. arRiyad: al-‘Arodaq al-Tajariniyah. 1989.

Amirin, Tatang M. Menyusun Rencana Penelitian. Jakarta: Rajawali Press, 1986

Arikunto, Suharsimi. Prosedur Penelitian. Jakarta: Rineka Cipta, 1989.

Chaer, Abdul. Linguistik Umum, Jakarta, Rineka Cipta, 1994.

http://ebsoft.web.id/KBBI v1.1. Kamus Besar Bahasa Indonesia.

Kridalaksana, Harimurti. Pembentukan Kata dalam Bahasa Indonesia, Edisi Kedua, Jakarta, PT Gramedia Pustaka Utama, 1996.

Samsuri. Analisis Bahasa "Memahami Bahasa Secara Ilmiah, Jakarta, Erlangga, 1987.

Sudaryat, Yayat. Makna Dalam Wacana "Prinsip-prinsip Semantik dan Pragmatik, Bandung, Alfabeta, 2006. 
82 Nailul Izzah, M. Agus Mushodiq, Muhammad Syaifullah: Semantics of Lexicology in the Study of Arabic....

HALAMAN INI SENGAJA DIKOSONGKAN 